\title{
Rape myth acceptance as a relevant psychological construct in a gender-unequal context: The Hungarian adaptation of the updated Illinois rape myths acceptance scale
}

\author{
Boglárka Nyúl $^{1,2}$ (1) Anna Kende ${ }^{2}$
}

Accepted: 12 March 2021 / Published online: 30 March 2021

(C) The Author(s) 2021

\begin{abstract}
The Updated Illinois Rape Myth Acceptance Scale (UIRMAS) has been widely used for measuring rape myth acceptance. The scale was created in the United States, however studies have shown that rape myth is a culturally and socially embedded phenomenon. Therefore, in order to measure rape myth acceptance in other parts of the world, the scale needs to be validated. Victim blaming and rape myths are both widespread in public reactions to rape in Hungary (i.e., in media reports and public opinion). Furthermore, Hungary can be characterized by a weak feminist movement and scoring low on gender equality measures. Nevertheless, we expected and found the reliability and validity of the Hungarian version of the Updated Illinois Rape myth acceptance Scale (UIRMAS). In Study 1 we conducted a confirmative factor analysis to assess the structural validity of the scale and identified the original factors of UIRMAS on a large convenience sample ( $N=758,25.4 \%$ men $74.6 \%$ women). In line with previous empirical evidence we also found that men, people with stronger just-world beliefs and higher sexism accepted rape myths more. In Study 2 we again found support for the original factor structure and construct validity of UIRMAS on a nationally representative sample $(N=1007,49.2 \%$ men $50.8 \%$ women), and also tested its convergent and discriminant validity. The results suggest that UIRMAS is a valid and reliable scale in the Hungarian context that can, for example, be used for measuring impact assessment of interventions.
\end{abstract}

Keywords Rape myth acceptance $\cdot$ Rape $\cdot$ UIRMAS $\cdot$ Scale $\cdot$ Adaptation

\section{Introduction}

"It's your fault, you can do something about it" was the slogan of a rape prevention campaign released by the police of Pécs, Hungary. The underlying message was that women's alcohol consumption, flirty behavior, and "inappropriate" clothing are invitations for rape. At the end of each video, the stereotypical perpetrator appeared: a scary looking stranger who follows women in dark alleys (Székely et al., 2015). The campaign met some public outrage because it supported rape myths, that is, the idea that on the one hand, rape is the victim's fault and on the other hand, it is connected to men's high sexual drive.

Boglárka Nyúl

nyul.boglarka@ppk.elte.hu

1 Doctoral School of Psychology, ELTE Eötvös Loránd University, Budapest, Hungary

2 Department of Social Psychology, ELTE Eötvös Loránd University, Budapest, Hungary
Therefore, we wanted to investigate the relevance of rape myth acceptance (RMA) as a psychological phenomenon in a social-cultural context which is not characterized by high level of gender equality (The Global Gender Gap Report, 2020), yet, there is growing awareness about rape and rape myths.

Although rape affects millions of people worldwide, the exact number is unknown. One out of five U.S. women experienced rape in her lifetime, and 1.3 million women reported some type of rape in the 12 months preceding a survey from 2010 (Ministry of Justice, Home Office, and Office for National Statistics, 2013). A much lower, but still very high prevalence was found in Europe: one out of 20 women experienced rape according to the estimations of the European Union Agency for Fundamental Rights (European Union Agency for Fundamental Rights, 2014). The difference in the numbers does not necessarily imply that there is indeed less cases of rape in Europe, it may simply reflect a higher latency of reporting rape. According to estimations, on average only 11 out of 100,000 report rape to the police, but this number greatly varies across countries (European Union 
Agency for Fundamental Rights, 2014). Most important factors that decrease the probability of reporting are experienced guilt, shame, embarrassment, fear of retaliation, and lack of trust in the police (Sable et al., 2006). All of the abovementioned factors are directly connected to rape myths and the beliefs that victims are to be blamed at least to some degree.

Rape myths are both descriptive and prescriptive beliefs about rape that serve to deny and justify male aggression against women (Bohner et al., 1998; Süssenbach \& Bohner, 2011) and trivialize its effects on the victim (Brownmiller, 1975; Suarez \& Gadalla, 2010). According to early theories, rape myths are specific domains of sexism that contribute to sexual aggression and coercion (Brownmiller, 1975) but separate from general rape attitudes because the main function of rape myth is to deny the pervasiveness of rape (Forbes, AdamCurtis, \& White, 2004; Lonsway \& Fitzgerald, 1994). Rape myths either put the blame on the victim (e.g., if a woman acts like a "slut", eventually she is going to get into trouble) or excuse the perpetrator (e.g., rape happens when a guy's sex drive goes out of control) by rationalizing rape (Burt, 1980; Payne et al., 1999). Rape myths are similar and connected to victim blaming and provide a feeling that the world is predictable and fundamentally just, and only those people get raped who somehow deserve it. Therefore, they are also consistent with just world beliefs (JWB; Lerner, 1980; Montada \& Lerner, 1998).

Rape myths and just world beliefs have similar psychological functions. They both reaffirm people's sense of security and control over their life (Gilmartin-Zena, 1988). Lerner (1980) argues that those who believe in a just world assume that the world is a fair place and bad things only happens to bad people as everyone gets what they deserve. Rape myths suggest something similar in the realm of sexual assaults. These beliefs serve to deny that rape can happen to anyone and decrease threat perceptions and anxiety. Despite these similarities, the connection between rape myth acceptance and just-world beliefs is ambiguous. Most previous studies found a positive association between the two (Hafer, 2000; Lonsway \& Fitzgerald, 1994; Vonderhaar \& Carmody, 2015), suggesting that an "innocent" rape victim is a threat to the belief that people always get what they deserve. Previous research also found that just-world beliefs are threatened, people tend to blame the victim more (Strömwall, Alfredsson, \& Landström, 2013). However, other studies found that the positive association exists only among women but not among men, (Sinclair \& Bourne, 1998; Lambert \& Raichle, 2000), and only when the victim is a woman (Lambert \& Raichle, 2000). Others found that RMA only correlates positively with just-world beliefs regarding others, but negatively with just-world beliefs regarding oneself (Hayes et al., 2013). This bias is in line with the assumption that people, especially women try to exclude themselves from the category of potential victims and distance themselves from victims (Bohner et al., 1998).

People accept rape myths to a different degree based on their gender, personal attitudes toward gender issues, and social norms. Although most people do not condone rape myths, men are less likely to dismiss such myths than women (e.g. Suarez \& Gadalla, 2010). One reason for this could be that they are more motivated to preserve gender inequality and the gender status quo than women. This is underlined by the fact that people in male-dominated societies would blame the victim, excuse the perpetrator, and justify the rape more than in less male-dominated societies (Suarez \& Gadalla, 2010). Although research consistently found that men support rape myths more, it is not necessarily gender, but gender identification that may drive this difference in RMA. Süssenbach and Bohner (2011) found that more highly identifying men endorsed rape myths more than lower identifying men, suggesting that not gender per se, but the endorsement of traditional masculine roles are associated with RMA. In contrast, the same study showed that highly identifying women endorsed rape myths less than low identifiers, which suggests that for women higher gender identification can also reflect a stronger feminist identification, explaining the negative association with RMA (Süssenbach \& Bohner, 2011).

Rape myth acceptance is strongly associated with oppressive beliefs (Suarez \& Gadalla, 2010), such as social dominance orientation (SDO). Social dominance orientation is an individual level variable, which indicates whether the person accepts hierarchical and unequal intergroup relations (Pratto et al., 1994). This belief tends to be higher among higher status social groups, such as men for example (Hantzi et al., 2015). SDO correlates positively with rape myth acceptance, which means that people who want to maintain existing social hierarchies and accept the oppression of lower status people also tend to endorse rape myths more (Pratto et al., 1994). Similarly to SDO, sexist beliefs also serve to maintain the status quo. This is underlined by the fact that people in male-dominated societies would blame the victim, excuse the perpetrator, and justify the rape more than in more equal societies (Suarez \& Gadalla, 2010). A meta-analytical review found that adversarial attitudes toward women, sexism, preference for male-dominance, pro status quo attitudes, and acceptance of rape (e.g. likelihood of raping and acceptability of rape) are all also positively correlated with rape myth acceptance, whereas male hostility (e.g. the belief that men's hostility toward women causes rape, and not male mental illness) and pro-feminist attitudes are negatively correlated with rape myth acceptance (Suarez \& Gadalla, 2010).

As rape occurs in a larger context of inequality between men and women, Chapleau and Oswald (2013) argue that gender inequality and sexual violence have a strong positive relation. They also found that people with higher system justification accept rape myth more, and this relation is equally 
strong for both men and women. These results suggest that those who generally consider current gender relations as fair would also think that women can be blamed for rape and men have no control over their sexual needs. Furthermore, classical sexism is strongly connected to attitudes toward rape, those who accept more traditional sex roles and gender inequality are more likely to endorse rape myths, even in more gender egalitarian soci eties, like Norway (see Bendixen et al., 2014). Furthermore, both hostile sexism (i.e. an overt hostility toward women's equality) and benevolent sexism (i.e. positive views of women in their traditional roles that maintain hierarchical gender relations) in society serve to justify and sustain male dominance over women in society, similarly to rape myth acceptance. Hostile sexism is, therefore, one of the strongest predictors of rape myth acceptance, and it correlates with rape myth acceptance more strongly than benevolent sexism (Glick et al., 2000; Viki \& Abrams, 2002; Viki et al., 2004). This is because similarly to hostile sexism, rape myths contain hostile attitudes toward women (Gerger et al., 2007). Benevolent sexism correlates with rape myth acceptance positively, but the association is weaker, because it does not entail directly hostile attitudes towards women as opposed to rape myths (Greger et al., 2007). Previous research found that people with higher benevolent sexism blame a female survivor more if she behaved inconsistently with the traditional female gender role (did not behave "ladylike", e.g., she wore revealing clothes, spoke to strangers, and drank alcohol) because according to benevolent sexist beliefs, these nontraditionally acting women do not deserve the protection that men provide to women (Abrams et al., 2003; Chapleau et al., 2007).

\section{Measuring Rape Myth Acceptance}

The first Rape Myth Acceptance Scale (RMAS, 19 items) was created by Burt (1980) to reflect the commonly held responses to sexual assaults and emphasized that the cultural function of rape myths is to normalize sexual violence and victim blaming. As the items in RMAS were unclear and overly complex, Lonsway and Fitzgerald (1994) developed a newer measure, the Illinois Rape Myth Acceptance Scale (IRMAS, 45 items). It aimed to capture the psychological mechanisms of victim blaming and contribute to understanding rape and its social consequences. Although IRMAS is one of the most reliable and widely used scales (Payne et al., 1999), its language became old-fashioned and it cannot capture subtle rape myths that are becoming more widespread than blatant aspects of RMA (McMahon \& Farmer, 2011). IRMAS shows a skewed distribution because of its overt items, that are no longer adequate to measure rape myth acceptance in the context of increased public awareness of rape myths (e.g. Hantzi et al., 2016, 30 items). Therefore, McMahon and Farmer (2011, 19 items) changed the items, updated the language, and eliminated three subscales from IRMAS and constructed the Updated Illinois Rape Myth Acceptance Scale (short form) to measure more contemporary and subtle forms of rape myths. It was used, for example, for longitudinally investigating the long-term effects of violent video gameplay on sexist attitudes and rape myth acceptance (Kühn et al., 2019), and exploring the relation between prior victimization, just world beliefs, and rape myth acceptance (Vonderhaar \& Carmody, 2015), and examining the role of rape myth acceptance in the evaluation of real rape cases (Nyúl et al., 2018), and exploring the relation between rape myth acceptance and bystander behavior (Bennett et al., 2017).

\section{Research Aims and Hypothesis}

According to the Global Gender Gap Index, Hungary holds the 105th position in equality of the positions of men and women in society (The Global Gender Gap Report, 2020), and it is the 40th on the United Nation's Gender Inequality Index (GGI, , 2019), suggesting that gender equality is lower than in most of the Western world. This means, that differences between men and women are larger than in Western countries. However, due to the lack of instruments and available data, we cannot compare the difference in the level rape myth acceptance. Therefore, because there is no validated questionnaire to measure rape myth acceptance in Hungary, we translated and tested the reliability, convergent and discriminant validity of the Updated Illinois Rape Myth Acceptance Scale (short form; UIRMA-SF), in two studies. Although comparing rape myth acceptance in Hungary to Western countries cross-culturally would be useful, in our research we only took the first step toward measuring rape myth acceptance in Hungary.

In the context of Hungary, we aimed and expected to replicate the original factor structure of the scale established in the U.S. context, as rape myths are connected to globalized ideas of gender relations, and despite clear economic, political and social differences, Hungary is culturally similar to most Western democracies. Furthermore, we also expected to replicate findings connected to convergent, construct, and discriminant validity from research conducted in the U.S. and other Western countries (e.g. McMahon, 2010; Trottier et al., 2020), and generally expected that the connections with other variables may be clearly identifiable because of the lower overall score on gender equality measures, the generally weak feminist movement and, consequently, the lack of strong normative expectations to withhold sexist ideas and hostile 
attitudes toward women and rape victims (The Global Gender Gap Report, 2020).

\section{Study 1}

Therefore, in Study 1 we expected to identify the original fivefactor solution of the UIRMA-SF scale, for convergent validity, we expected higher rape myth acceptance among men than among women (H1); for construct validity a positive relationship between UIRMA-SF and hostile sexism meaning that people who accept rape myth acceptance more will accept hostile sexism more (H2); and to test discriminant validity for positive but weak correlations with similar and related attitudes to rape myth acceptance. Therefore, we expect that people who accept rape myth more will also score higher on benevolent sexism and just world beliefs more (H3).

We conducted our first study in 2014. It must be noted that it was before the \#MeToo movement which received widespread attention worldwide, including Hungary (Kovács \& Szémann, 2018). Although rape cases were often reported in the media relying on rape myth previously, following the \#MeToo movement, public awareness and the social context has undoubtedly changed, which may translate into general changes in attitudes toward sexual assault and rape that we could not account for in this study.

\section{Materials and Methods}

\section{Participants}

Participants were recruited in two different ways. We collected data amongst undergraduate students $(n=77 ; 54.5 \%$ men, age $M=21.31$ years; $S D=1.58)$ and recruited participants online from a community sample $(n=681 ; 22.2 \%$ men, age $M=28.66$ years; $S D=10.67$ ) using convenience sampling. The final sample size was $N=758(25.4 \%$ men; age $M=$ 27.91 years; $S D=10.37$ )

\section{Measures and Procedure}

We used a paper-and-pencil questionnaire for the student sample and an online questionnaire in the community sample. We conducted the research following the IRB approval of anonymous university. We report all data exclusions and measures that are relevant to the scale validation both in Study 1 and in Study 2.

After giving informed consent to participating in a study about men's and women's roles in society and attitudes toward sexual violence, participants completed the validated Hungarian version of the Ambivalent Sexism Inventory (the 10 -item hostile sexism scale, $\alpha=.89$; and the 11-item benevolent sexism scale, $\alpha=.86$; Glick \& Fiske, 1996, Hungarian version Szabó, 2008), the validated Hungarian version of Belief in a Just World Scale ( 8 items, $\alpha=.84$; Dalbert, 1999, Hungarian version Berkics, 2008), and the Updated Illinois Rape Myth Acceptance Scale (18 items, $\alpha=.91$; McMahon \& Farmer, 2011). Although, McMahon and Farmer (2011) used a 5-point Likert scale, because other measures of the study relied on 7-point scales, we administered UIRMA also with a 7-point scale for consistency and because previous evidence suggests that a 5-point scale can be readily transformed into a 7-point scale (from $1=$ completely disagree to 7 = completely agree; see Dawes, 2008). Although, the original scale contained 19 items, we did not administer the item 'Girls who are caught cheating on their boyfriends sometimes claim that it was a rape' because this question number was mistakenly not presented in the figure of the original paper (McMahon \& Farmer, 2011), therefore we only used 18 items. The item originally loaded on the 5 th factor and it was the weakest item of the subscale. Following the guidelines (Beaton et al., 2000) for instrument translation, the items of UIRMA-SF were translated into Hungarian. After the backtranslation the scale was reviewed by Dr. McMahon, one of the authors of the original scale.

\section{Statistical Analysis Plan}

We performed confirmatory factor analysis on the data based on the factor structure provided by McMahon and Farmer (2011). Confirmatory factor analysis (CFA) is a multivariate statistical procedure, and contrary to exploratory factor analysis (EFA) which explores information about the number of required factors, in CFA the number of factors and the relationship between measured and latent variables can be specified. Therefore, it can be used to test whether the factor structure of a scale is replicable on a different sample. CFA also shows the goodness of fit of the examined model. Due to nonnormality of the distribution of several ratings, we used MLR estimator, which is an Mplus option for maximum likelihood estimation with robust standard errors (Muthén \& Muthén, 2017). CFA was performed with MPlus 8 (Muthén \& Muthén, 2015, 2009). A satisfactory degree of fit of comparative fit index (CFI) and Tucker-Lewis Index (TLI) is close or higher than 0.95 and the model has to be rejected if these indices are under 0.90 (Brown, 2006). The root mean square error of approximation (RMSEA) below 0.05 indicates excellent, around 0.08 adequate, and above 0.10 a poor fit. Standardized Root Mean Square Residual (SRMR) is an index of the average of standardized residuals between the observed and the hypothesized covariance matrices (Chen, 2007). The value of SRMR indicates good fit under 0.05 and adequate around 0.08. To confirm convergent validity, we compared RMA of men and women, and to confirm discriminant validity we tested the connection 
between hostile sexism, benevolent sexism, and just-world beliefs using parametric or non-parametric method depending on the distribution.

\section{Results}

The five-factor model provided a good fit $(\chi 2=353.687, \mathrm{df}=$ $124, \mathrm{CFI}=.954$, TLI $=.943 \mathrm{RMSEA}=.049[.043 ; .056]$, SRMR $=.051)$. Our analysis confirmed the following five original factors: (1) She lied $(\alpha=.88)$, (2) She asked for it $(\alpha=.88)$, (3) It wasn't really rape $(\alpha=.74)$, (4) He didn't mean to $(\alpha=.71)$, (5) He didn't mean to (intoxication) $(\alpha=.58){ }^{1}$ Before comparing UIRMA across gender and prior experience of rape, the factor structure was tested for measurement invariance (see Brown, 2006). Scalar invariance was established across gender (see Table 1), as indices diminished less than the recommended values (.10 for CFI and TLI; .015 for RMSEA; Chen, 2007). The five factors of UIRMA can be separated both statistically and theoretically (see McMahon \& Farmer, 2011), however, the multicollinearity between the factors and the correlation of the factors with the whole scale is high (.32-.67 see Fig. 1), and the factors are related to the main concept strongly, and do not describe a different phenomenon. Based on confirmatory factor analysis the factor structure of the scale is adequate, therefore, we did not change the original factor structure, but internal consistency of the 5th factor was lower than acceptable. Therefore, in Study 1 to test the validity we describe the relationship between, on the one hand, the measured variables and, on the other hand, both rape myth acceptance and its subscales. These two uses of the UIRMA is justified by the fact that UIRMA captures describes RMA as a single concept, and therefore, the distinction between the subscales is not necessary(e.g. Peterson et al., 2018).

Convergent and Discriminant Validity UIRMA data was nonnormally distributed with skewness of $.650(\mathrm{SE}=.089)$ and with kurtosis of .051 (SE = .177). However, this level of skewness does not affect the analysis, therefore, we used independent sample t-test to test gender differences. Men scored significantly higher on all five factors and on rape myth acceptance than women, but these differences are slightly less than moderate (based on computation of the effect sizes with the program of Lenhard \& Lenhard, 2016; for more information on the differences, see Table 2). Overall, these scores indicate that the general acceptance of rape myths is not high.

Hostile sexism strongly positively, while benevolent sexism moderately positively correlated with RMA and just-

\footnotetext{
${ }^{1}$ We also run a 4 factor model merging of two „He didn't mean to" factors to increase the reliability of the scale, which increased to $\alpha=.70$ but the fit of the model was not as good as in case of the 5-factor model $(\chi 2=637.680$, $\mathrm{df}=129, \mathrm{CFI}=.898, \mathrm{TLI}=.879 \mathrm{RMSEA}=.072[.067 ; .078], \mathrm{SRMR}=.069)$
}

world beliefs correlated positively but weakly with rape myth acceptance and its subscales (see Table 3). In line with our expectations, hostile sexism correlated more strongly with RMA than benevolent sexism (Cohen's q = .24).

\section{Discussion of Study 1}

Study 1 confirmed the adequacy of the five-factor solution of the rape myth acceptance scale as suggested by McMahon and Farmer (2011). The proposed 5-factor structure indicated a good fit to the data, but the correlation between the scales was also strong.

Although differences were small, our results supported the hypotheses that men accepted rape myths more (H1), people with higher rape myth acceptance endorsed hostile sexism (H2) and benevolent sexism more, and in line with previous research, people with higher rape myth acceptance believed more in a just world (H3) (e.g. European Commission, 2016; Frese, Moya, \& Megías, 2016; Parti, 2002). Furthermore, in line with previous results (Dénes, 2000; Hayes et al., 2013) we found that the correlation between rape myth acceptance and hostile sexism was stronger than the correlation between benevolent sexism and rape myth acceptance. Although the two sexist attitudes are closely related and they are both positively associated with rape myth acceptance, this difference can be explained by the fact that benevolent sexism serves to justify men's dominance over women, hence it is related to rape myth acceptance, but it does not contain aggressive and punishing attitudes toward women that both rape myth acceptance and hostile sexism entails (Bohner et al., 1998).

Although our results gave us the first indication that the psychological mechanisms connected to rape myth acceptance apply in the context of Hungary, and the translated version of McMahon and Farmer's (2011) scale is adequate, the results are limited by the type of sample that we used, because participants were recruited using convenience sampling and overwhelmingly among university students. Therefore, we conducted Study 2 to examine the phenomenon using a sample demographically similar to the Hungarian population.

\section{Study 2}

Although these results gave us the first indication that the psychological mechanisms connected to rape myth acceptance work similarly in the context of Hungary as in other previously studied contexts, and the translated version of McMahon and Farmer's (2011) scale is adequate, generalizability of the results of Study 1 are limited by the type of sample that we used. Therefore, we extended our study to find further evidence for the phenomenon using a sample representative to the Hungarian population. The aim of Study 2 was to further test the validity of UIRMA on a Hungarian representative sample. Furthermore, we wanted to 
Table 1 Measurement invariance across the male and female subsamples in Study 1

\begin{tabular}{llllllllll}
\hline Model & $\chi^{2}(\mathrm{df})$ & CFI & TLI & RMSEA & $90 \%$ CI & $\Delta \chi^{2}(\mathrm{df})$ & $\Delta$ CFI & $\Delta$ TLI & $\Delta$ RMSEA \\
\hline Configural & $514.500(248)$ & .950 & .938 & .053 & $.047-.060$ & & & \\
Metric & $527.431(262)$ & .950 & .942 & .052 & $.045-.058$ & $12.931(14)$ & 0.000 & 0.004 & -0.001 \\
Scalar & $598.687(275)$ & .939 & .933 & .056 & $.050-.062$ & $71.256(13)$ & -0.011 & -0.009 & 0.004 \\
\hline
\end{tabular}

extend our research to establish the construct and discriminant validity of the scale more thoroughly. Therefore, we examined the connection between gender system justification, social dominance orientation, on the one hand, and rape myth acceptance on the other. Similarly to Study 1 we aimed to check the five-factor solution of the UIRMA-SF scale, and expected that men accept rape myths more than women $(\mathrm{H} 1)$; moderate positive relationship between UIRMA-SF and gender system justification (H2), a strong positive relationship between UIRMA-SF and hostile sexism (H3); a moderate positive correlations with benevolent sexism (H4); and a moderate positive relationship with social dominance orientation (H5)..

\section{Materials and Methods}

\section{Participants}

We relied on a sample representative to the Hungarian society in terms of gender, age, and type of settlement, but participants
Fig. 1 Confirmatory factor analysis of the Updated Illinois Rape Myth Acceptance Scale (SF). All factor loadings are standardized and significant $(p<.01)$




Table 2 Differences between men and women on UIRMA and on its subscales

\begin{tabular}{|c|c|c|c|c|c|}
\hline & $\operatorname{men}(n=193)$ & women $(n=562)$ & & & \\
\hline & Mean (SD) & Mean (SD) & $\mathrm{t}$ & $\mathrm{p}$ & Cohen's d \\
\hline Rape myth acceptance (full scale (18 items) & $2.97(1.00)$ & $2.57(1.04)$ & 4.68 & $p<.001$ & .039 \\
\hline "She lied" (4 items) & $3.12(1.37)$ & $2.49(1.32)$ & 5.69 & $\mathrm{p}<.001$ & .048 \\
\hline "She asked for it" (4 items) & $3.47(1.64)$ & $3.14(1.65)$ & 2.39 & $p=.017$ & .20 \\
\hline "Wasn't really rape" (4 items) & $2.21(1.17)$ & $1.85(1.11)$ & 3.84 & $\mathrm{p}<.001$ & .32 \\
\hline "He didn't mean to" (4 items) & $3.45(1.24)$ & $3.18(1.31)$ & 2.53 & $p=.012$ & .21 \\
\hline "He didn't mean to (intoxication)" (3 items) & $1.95(1.04)$ & $1.72(1.00)$ & 2.61 & $p=.009$ & .218 \\
\hline
\end{tabular}

had a higher than average education ( $N=1007,49.2 \%$ men $)$. We did not calculate sample size based on the effect sizes of Study 1 , and targeted $N=1000$ which is typically used in representative opinion poll surveys in Hungary (see Poll of Polls, 2018), but also adequate to test the effect sizes identified in Study 1.

We recruited participants with the help of an opinion poll company (Solid Data) who selected participants from an online pool of respondents that are representative to the Hungarian society in terms of gender, age, and type of settlement, but participants had a higher than average education $(N=1007,49.2 \%$ men). Mean age was 41.52 years $(S D=$ 13.05) ranging from 18 to 64 years. Demographic information is presented in Table 4.

\section{Measures and Procedure}

Data was collected in 2016, as part of an omnibus survey with research focusing on different social psychological phenomena. The language of the questionnaire was Hungarian. After giving their consent, participants completed the short form of the Ambivalent Sexism Inventory (the 5-item hostile sexism scale, $\alpha_{\text {hostile }}=.84$; the 5 -item benevolent sexism scale $\alpha_{\text {benevolent }}=.79$; Glick \& Fiske, 1996, Hungarian version: Szabó, 2008). Due to the type of data collection (omnibus survey) the number of items we could include in our study was limited, therefore we used the short form of this questionnaire. After that they completed the Hungarian version of the Updated Illinois Rape Myth Acceptance Scale (18 items, $\alpha=.90$; McMahon \& Farmer, 2011). Then to examine the validity of the Scale more thoroughly we also measured gender system justification with the Modern Sexism Scale (5 items, $\alpha=.75$; Swim et al., 1995), and social dominance orientation ( 8 items, $\alpha=$.78; Ho et al., 2015, Hungarian version: Faragó \& Kende, 2017).

\section{Statistical Analysis Plan}

To check whether the five-factor solution can be identified on a representative sample, we performed confirmatory factor analysis again based on the factor structure suggested by McMahon and Farmer (2011) and tested in Study 1. Again, due to non-normality of the distribution of several ratings, we used MLR estimator. CFA were performed with MPlus 8 (Muthén \& Muthén, 2015-Muthén \& Muthén, 2009). To confirm convergent validity, we compared RMA of men and women, and to confirm construct and discriminant validity, we planned to test the relation between gender system justification, hostile and benevolent sexism, and social dominance
Table 3 Pearson correlations between hostile sexism, benevolent sexism, just-world beliefs, UIRMA and its subscales

\begin{tabular}{lllllllll}
\hline & 1 & 2 & 3 & 4 & 5 & 6 & 7 & 8 \\
\hline 1 Hostile sexism (10 items) & - & & & & & & \\
2 Benevolent sexism (11 items) & .45 & - & & & & & \\
3 Just world beliefs (8 items) & .16 & .11 & - & & & & \\
4 Rape myth acceptance (full scale, 18 items) & .44 & .62 & .17 & - & & & \\
5 "She lied" (4 items) & .31 & .59 & .08 & .82 & - & & \\
6 "She asked for it" (4 items) & .39 & .54 & .10 & .84 & .62 & - & \\
7 "Wasn't really rape" (4 items) & .32 & .41 & .21 & .76 & .58 & .50 & - \\
8 "He didn't mean to" (4 items) & .38 & .39 & .15 & .67 & .36 & .47 & .55 & - \\
9 "He didn't mean to (intoxication)" (3 items) & .24 & .34 & .12 & .67 & .47 & .42 & .48 & .55 \\
\hline
\end{tabular}

Significance is below $\mathrm{p}<.001$ in each cell. Bootstrapping $=1000$. 
Table 4 Level of education and settlement type of participants

\begin{tabular}{lll}
\hline & $\mathrm{N}$ & $\%$ \\
\hline Education & & \\
Primary degree or less & 8 & 0.8 \\
Secondary degree & 464 & $46.1 \%$ \\
Vocational education and training & 118 & $11.7 \%$ \\
College/university degree or higher & 417 & $41.5 \%$ \\
Settlement & & \\
Capital & 191 & $19 \%$ \\
County capital & 212 & $21.1 \%$ \\
Town & 331 & $32.9 \%$ \\
Village & 273 & $27 \%$ \\
\hline
\end{tabular}

orientation using parametric or non-parametric method depending on the distribution.

\section{Results}

The five-factor model showed good fit to the data $\left(\chi^{2}=\right.$ 421.850, $\mathrm{df}=124, \mathrm{CFI}=.944, \mathrm{TLI}=.931 \mathrm{RMSEA}=.054$ [.048; .060], SRMR =.049). We found the same 5 factors as in Study 1 (1) She lied $(\alpha=.92)$, (2) She asked for it $(\alpha=.83)$, (3) It wasn't really rape $(\alpha=.75)$, (4) He didn't mean to ( $\alpha=.68)$, (5) He didn't mean to (intoxication) $(\alpha=.66){ }^{2}$ Standardized factor loadings of the general factor ranged from 0.31 to 0.90 (see Fig. 2.). Measurement invariance (see Brown, 2006), and scalar invariance of the UIRMA scale was established across gender groups (see Table 5).

Convergent and Discriminant Validity Because of non-normal distribution (skewness of $.307, \mathrm{SE}=.077$ and kurtosis of $-.130 \mathrm{SE}=.154$ ) we used Mann-Whitney test to compare the UIRMA scores of men and women (see Table 6). Men scored significantly higher than women on rape myth acceptance and on every subscale of UIRMA, except on subscale He didn't mean to (intoxication), however these differences were small, and lower than in the previous study. Overall, the mean score shows that people accept rape myth on a low level.

As predicted, UIRMA correlated moderately positively with gender system justification (Spearman's $\rho=.41$, $p<.001$ ) hostile sexism (Spearman's $\rho=49, p<.001$ ) indicating convergent validity (see Table 7 ) and correlated weakly with benevolent sexism (Spearman's $\rho=.24, p<.001$ ) and with social dominance orientation (Spearman's $\rho=.23, \mathrm{p}$ $<.001)$. Similarly to Study, 1 we found that rape myth

\footnotetext{
${ }^{2}$ We also run a 4 factor model merging two „He didn't mean to" factors. The reliability of the scale increased to $\alpha=.71$, but the fit of the model was again worse than in case of the 5 -factor model $(\chi 2=1086.046, \mathrm{df}=147, \mathrm{CFI}=.863$, $\mathrm{TLI}=.841 \mathrm{RMSEA}=.080[.075 ; .084], \mathrm{SRMR}=.105)$ "
}

acceptance correlates slightly more strongly with hostile sexism than with benevolent sexism (Cohen's q = .29).

Furthermore, we compared rape myth acceptance in Study 1 and 2 with an independent sample t-test and found that rape myth acceptance was significantly higher in the sample of Study 2 (see Table 8).

\section{Discussion of Study 2}

The aim of Study 2 was to test the factor structure of the Updated Illinois Rape Myth Acceptance Scale using a representative sample and to examine the validity of the Scale with more variables. Similarly to Study 1, we found the five-factor structure of the Scale adequate and confirmed invariance between men and women. We found that men accepted rape myths more than women. However, this difference was small, and in line with previous studies (see Suarez \& Gadalla, 2010) supported the convergent validity of the Scale. As in Study 1, we found that those who endorsed rape myths more, also accepted hostile sexism and benevolent sexism more, which result strengthens construct validity. However, these associations were weaker than we expected. As a novelty of Study 2, we measured social dominance orientation and gender system justification. In line with Pratto's (1994) suggestions, we found that people with higher social dominance orientation accepted beliefs about rape more. This result means that people who want to maintain existing social hierarchies and accept the oppression of lower status people are also more likely to endorse rape myths. Our results are in line with the findings of other studies suggesting that higher social dominance orientation is connected to higher victim blaming (Canto et al., 2020), and higher rape myth acceptance (Manoussaki \& Hayne, 2019), found even in case of police officers (Murphy \& Hine, 2019). Similarly to Chapleau et al. (2007), we found that those with higher gender system justification accepted rape myths more, which means that people who think that gender differences are justifiable and men deserve their higher status are more likely blame the victim and exonerate the perpetrator for rape. Furthermore, the results imply, similarly to the findings of Papp and Erchull (2017), that both men and women's attitudes about society affect their endorsement of rape myths.

\section{General Discussion}

The main aim of our research was to test the validity of a scale measuring rape myth acceptance in Hungarian, in Hungary, as this measure had been missing. Considering some important differences (e.g, level of gender equality, strength of feminist movement, and overall attitudes toward rape victims) in the context of Hungary and the U.S. where the scale was 
Table 5 Measurement invariance across the male and female subsamples in Study 2

\begin{tabular}{llllllllll}
\hline Model & $\chi^{2}(\mathrm{df})$ & CFI & TLI & RMSEA & $90 \%$ CI & $\Delta \chi^{2}(\mathrm{df})$ & $\Delta$ CFI & $\Delta$ TLI & $\Delta$ RMSEA \\
\hline Configural & $649.965(284)$ & .937 & .924 & .056 & $.050-.061$ & & & \\
Metric & $657.909(298)$ & .938 & .929 & .054 & $.048-.060$ & $7.944(14)$ & .001 & .005 & -.002 \\
Scalar & $693.627(312)$ & .935 & .928 & .054 & $.049-.060$ & $35.718(14)$ & -.003 & -.001 & .000 \\
\hline
\end{tabular}

originally developed, it was important to check whether the scale can capture rape myth acceptance similarly to its original place of development. Furthermore, this result suggests that the structure of rape myths is similar to Western countries, where gender differences are smaller than in Hungary.

Both Study 1 and 2 confirmed the adequacy of the fivefactor solution of the rape myth acceptance scale as suggested by McMahon and Farmer (2011), the translated scale showed good internal consistency, and satisfactory convergent validity. The proposed 5-factor structure indicated a good fit to the data, however, the correlation between the scales were strong. This suggests that following the example of other studies (e.g. Debowska et al., 2015, Peterson et al., 2018, Reling et al., 2018) we are confident that it is possible to use UIRMA as a single-scale measure in Hungarian as well.

Furthermore, throughout two studies we also tested measurement invariance between men and women. Our results supported the assumption that the measurement model was
Fig. 2 Confirmatory factor analysis of the Updated Illinois Rape Myth Acceptance Scale (SF). All the factor loadings are standardized and significant $(p<.01)$

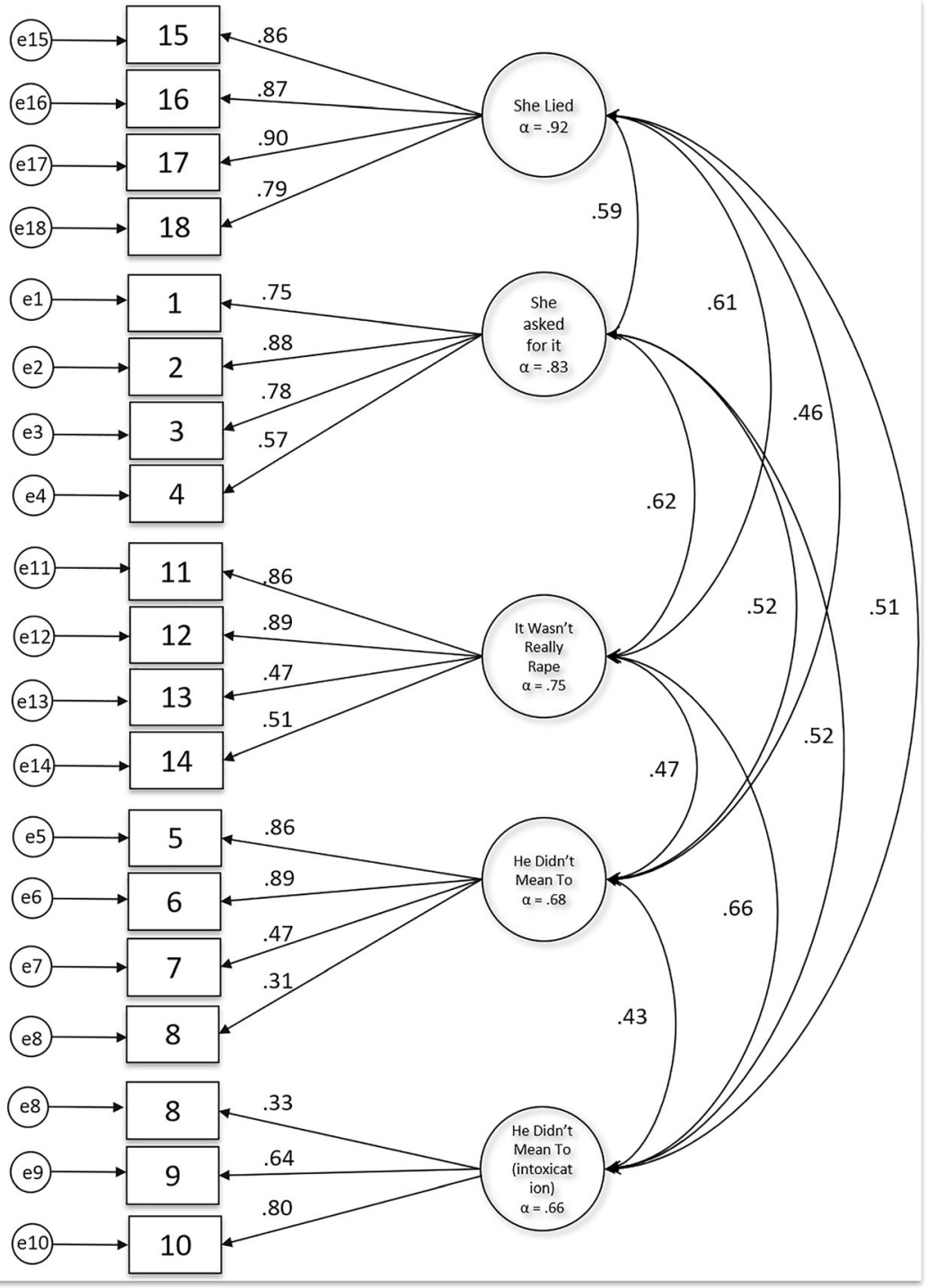


Table 6 Differences between men and women on UIRMA and on its subscales

\begin{tabular}{|c|c|c|c|c|c|}
\hline & $\operatorname{Men}(n=495)$ & Women $(n=512)$ & & & \\
\hline & Mean (SD) & Mean (SD) & $\mathrm{t}$ & $\mathrm{p}$ & Cohen's d \\
\hline Rape myth acceptance (full scale, 18 items) & $3.50(1.11)$ & $3.30(1.23)$ & 2.73 & $p=.006$ & .17 \\
\hline "She lied" (4 items) & $3.80(1.57)$ & $3.22(1.61)$ & 5.78 & $\mathrm{p}<.001$ & .37 \\
\hline "She asked for it" (4 items) & $3.84(1.49)$ & $4.11(1.71)$ & -2.68 & $p=.008$ & .17 \\
\hline "Wasn't really rape" (4 items) & $2.90(1.46)$ & $2.64(1.43)$ & 2.79 & $p=.005$ & .18 \\
\hline "He didn't mean to" (4 items) & $3.82(1.29)$ & $3.60(1.50)$ & 2.54 & $p=.011$ & .16 \\
\hline "He didn't mean to (intoxication)" (3 items) & $2.38(1.37)$ & $2.27(1.40)$ & 1.22 & $p=.222$ & - \\
\hline
\end{tabular}

invariant across gender, which means that ideas concerning rape myth are identically present (or absent) among men and women, regardless of the fact that victims are presented as women and perpetrators as men in the scale. Although differences were small, our results throughout both studies supported the hypotheses that men accepted rape myths more that supports the scale's convergent validity. People with higher rape myth acceptance endorsed gender system justification, hostile sexism, benevolent sexism and social dominance orientation more, that supports the scale's construct validity, and in line with previous research, people with higher rape myth acceptance believed more in a just world, which strengthens the scale's discriminant validity (e.g. Lonsway \& Fitzgerald, 1994; Suarez \& Gadalla, 2010; Vonderhaar \& Carmody, 2015). Furthermore, in line with previous results (Greger et al., 2007; Katerina \& Bohner, 2015), we found that the correlation between rape myth acceptance and hostile sexism was stronger than the correlation between benevolent sexism and rape myth acceptance. Although the two sexist attitudes are closely related and they are both positively associated with rape myth acceptance, this difference can be explained by the fact that benevolent sexism serves to justify men's dominance over women, hence it is related to rape myth acceptance, but it does not contain aggressive and punishing attitudes toward women that both rape myth acceptance and hostile sexism entails (Glick et al., 2000). Furthermore, these results suggest that the correlates of rape myth acceptance are similar to Western countries, and its connections with other variables can be clearly identified. Although our research was not cross-cultural, it would be interesting to compare the power of these connections, because of the higher gender inequality and the lack of strong normative expectations to withhold sexist ideas and hostile attitudes toward women and rape victims in Hungary compared to the U.S. (The Global Gender Gap Report, 2020) which could potentially cause a stronger association between the variables than in more egalitarian countries (see e.g. Hantzi et al., 2016).

We also found that although people did not endorse rape myths very highly, the level of rape myth acceptance was significantly higher among the participants of Study 2. This result may be explained by the fact that in Study 1 we relied on a convenience sample consisting of younger and more highly educated participants than in the representative sample of Study 2. This is partially in line with the findings of Suarez and Gadalla (2010) who did not find a relationship between age and rape myth acceptance in their meta-analysis, but they found that education
Table 7 Pearson correlation between gender system justification, hostile sexism, benevolent sexism, social dominance orientation, UIRMA and its subscales

\begin{tabular}{|c|c|c|c|c|c|c|c|c|c|}
\hline & 1 & 2 & 3 & 4 & 5 & 6 & 7 & 8 & 9 \\
\hline 1 Gender system justification ( 5 items) & - & & & & & & & & \\
\hline 2 Hostile sexism (5 items) & .60 & - & & & & & & & \\
\hline 3 Benevolent sexism (5 items) & .12 & .14 & - & & & & & & \\
\hline 4 Social Dominance Orientation ( 8 items) & .31 & .32 & $.01 \mathrm{~ns}$ & - & & & & & \\
\hline 5 Rape myth acceptance (full scale, 18 items) & .41 & .50 & .26 & .24 & - & & & & \\
\hline 6 "She lied" (4 items) & .38 & .55 & .18 & .23 & .80 & - & & & \\
\hline 7 "She asked for it" (4 items) & .31 & .39 & .22 & .18 & .78 & .52 & - & & \\
\hline 8 "Wasn't really rape" (4 items) & .35 & .36 & .16 & .18 & .81 & .60 & .50 & - & \\
\hline 9 "He didn't mean to" (4 items) & .22 & .23 & .26 & .11 & .66 & .36 & .41 & .38 & - \\
\hline 10 "He didn't mean to (intoxication)" (3 items) & .27 & .27 & .14 & .16 & .68 & .42 & .42 & .52 & .55 \\
\hline
\end{tabular}

Ns - not significant. In every other case significance is below $\mathrm{p}<.001$ in each cell. Bootstrapping $=1000$. 
Table 8 Comparison of the rape myth acceptance in Study 1 and Study 2 with a paired sample t-test

\begin{tabular}{|c|c|c|c|c|c|}
\hline & Study $1(n=758)$ & Study $2(n=1007)$ & & & \\
\hline & Mean (SD) & Mean (SD) & $\mathrm{t}$ & $\mathrm{p}$ & Cohen's d \\
\hline Rape myth acceptance (full scale, 18 items) & $2.67(1.04)$ & $3.40(1.18)$ & -13.78 & $\mathrm{p}<.001$ & .66 \\
\hline "She lied" (4 items) & $2.65(1.36)$ & $3.50(1.62)$ & -12.02 & $\mathrm{p}<.001$ & .58 \\
\hline "She asked for it" (4 items) & $3.23(1.66)$ & $3.98(1.62)$ & -9.55 & $\mathrm{p}<.001$ & .46 \\
\hline "Wasn't really rape" (4 items) & $1.94(1.13)$ & $2.77(1.45)$ & -13.56 & $\mathrm{p}<.001$ & .65 \\
\hline "He didn't mean to" (4 items) & $3.24(1.30)$ & $3.71(1.40)$ & -7.19 & $\mathrm{p}<.001$ & .35 \\
\hline "He didn't mean to (intoxication)" (3 items) & $1.78(1.01)$ & $2.33(1.39)$ & -9.50 & $\mathrm{p}<.001$ & .46 \\
\hline
\end{tabular}

negatively correlated with rape myth acceptance: those who accepted rape myths more were less educated.

Using a representative sample in Study 2 enabled us to generalize our findings to the Hungarian context. In both studies we found evidence for convergent and discriminant validity of the scale, suggesting that RMA is part of a generalized hostility toward women and gender equality (Süssenbach \& Bohner, 2011) and it is deeply embedded in societies beliefs systems about gender roles and inequality. At the same time, measuring rape myth acceptance can offer a better understanding of rape related attitudes than more general ideologies about gender or about victim blaming in general (e.g. through just-world beliefs).

Rape myths serve to justify men's sexual aggression over women (Lonsway \& Fitzgerald, 1994), and mask the structural aspects of rape (Chapleau et al., 2007). This explanation is supported by data suggesting that rape myths are more accepted in more conservative and less gender equal societies (Aosved \& Long, 2006; Foster \& Kidd, 2014). It is for this reason that gender differences - even if they are small - in RMA can be found in more gender unequal societies like Hungary.

\section{Limitations and Future Directions}

Because there is no other RMA scale available in Hungarian, another pitfall of the research was that we did not use any other scale to measure RMA. For the sake of validity, it would have been useful to test the relationship between UIRMAS and another RMA scale. Although other studies tested the validity between IRMAS and different measures (e.g. with Acceptance of Modern Myths about Sexual Aggression, Hantzi et al., 2016) and they found that the scale was a valid measure of rape myth, we could not directly test this.

Another weakness of the scale is the reliability of its 5th factor. Because the factor structure was adequate based on the CFA, we did not modify it. Future research could focus on the 5th factor and develop more items to achieve better reliability.

An asset of this study is that we tested UIRMA in an underrepresented region of social psychological research, and especially of research on rape and rape myths. Furthermore, this region is not only underrepresented in these research areas, but the level of sexism is higher and gender equality is lower in
Hungary than in the US or in Western Europe (The Global Gender Gap Report, 2020) where most studies related rape myth had been carried out. This is important because RMA is not only related to personal attitudes and characteristics, such as a person's gender, just-world beliefs, but also to societal factors, such as oppressive beliefs, like sexism and gender system justification. Therefore, the adaptation of the scale gives the opportunity for further research to test relations and mechanism in an underrepresented and highly gender inequal country.

In conclusion, our results show that rape myth acceptance is a related, but clearly distinguishable construct from gender system justification, just world beliefs, sexism, and social dominance orientation, therefore, it is important to measure it separately to grasp attitudes towards rape. Importantly, our findings suggest that the psychological mechanisms regarding RMA function similarly in the less gender equal context of Hungary to Western and more gender equal contexts. Properly measuring rape myth acceptance can become the first step toward the assessment of prevention and education programs regarding rape. Using this scale will not only enable measuring the level of rape myth acceptance, but also how it changes due to interventions in Hungary. Furthermore, highlighting gender differences in rape myth acceptance can help design better programs, as change is expected to be reached differently for those high or low in their original attitudes. However, our findings about the low overall scores also showed that the language of the McMahon and Farmer's (2011) scale could be further refined to become even more subtle as there is a growing awareness of rape myths in society.

Acknowledgements Open access funding provided by Eötvös Loránd University.

Data Availability Databases are available on OSF ont he following link: https://osf.io/mb2sn/?view_only=e7003626fb7448df8019c57d2a61ae9f

\section{Declarations}

Ethical Statement This study was carried out in accordance with the recommendations of Ethical Guidelines and Ethical Committee of Eötvös Loránd University with informed consent from all subjects. 
Conflicts of Interest/Competing Interests The authors declare that they have no conflict of interest.

Open Access This article is licensed under a Creative Commons Attribution 4.0 International License, which permits use, sharing, adaptation, distribution and reproduction in any medium or format, as long as you give appropriate credit to the original author(s) and the source, provide a link to the Creative Commons licence, and indicate if changes were made. The images or other third party material in this article are included in the article's Creative Commons licence, unless indicated otherwise in a credit line to the material. If material is not included in the article's Creative Commons licence and your intended use is not permitted by statutory regulation or exceeds the permitted use, you will need to obtain permission directly from the copyright holder. To view a copy of this licence, visit http://creativecommons.org/licenses/by/4.0/.

\section{References}

Abrams, D., Viki, G., Masser, B., \& Bohner, G. (2003). Perceptions of stranger and acquaintance rape: The role of benevolent and hostile sexism in victim blame and rape proclivity. Journal of Personality and Social Psychology, 84, 111-125. https://doi.org/10.1037/00223514.84.1.111.

Aosved, A. C., \& Long, P. J. (2006). Co-occurrence of, sexism, racism, homophobia, ageism, classism, and religious intolerance. Sex Roles, 55, 481-492. https://doi.org/10.1007/s11199-006-9101-4.

Beaton, D. E., Bombardier, C., Guillemin, F., \& Ferraz, M. B. (2000). Guidelines for the process of cross-cultural adaptation of self-report measures. Spine, 25, 3186-3191. https://doi.org/10.1097/ 00007632-200012150-00014

Bendixen, M., Henriksen, M., \& Nøstdahl, R. K. (2014). Attitudes toward rape and attribution of responsibility to rape victims in a Norwegian community sample. Nordic Psychology, 66, 168-186. https://doi. org/10.1080/19012276.2014.931813.

Bennett, S., Banyard, V. L., \& Edwards, K. M. (2017). The impact of the bystander's relationship with the victim and the perpetrator on intent to help in situations involving sexual violence. Journal of Interpersonal Violence, 32, 682-702. https://doi.org/10.1177/ 0886260515586373

Berkics, M. (2008). A társadalmi viszonyok és a társadalomban zajló versengés igazságosságának észlelése. $\mathrm{PhD}$ Dissertation, ELTE.

Bohner, G., Reinhard, M.-A., Rutz, S., Sturm, S., Kerschbaum, B., \& Effler, D. (1998). Rape myths as neutralizing cognitions: Evidence for a causal impact of anti-victim attitudes on men's self-reported likelihood of raping. European Journal of Social Psychology, 28, 257-268. https://doi.org/10.1002/(SICI)1099-0992(199803/04)28: 2<257::AID-EJSP871>3.0.CO;2-1.

Brown, T. A. (2006). Confirmatory factory analysis for applied research. Guilford Press.

Brownmiller, S. (1975). Against our will: men, women, and rape. New York: Simon and Schuster.

Burt, M. R. (1980). Cultural myths and supports for rape. Journal of Personality and Social Psychology, 38, 217-230. https://doi.org/ 10.1037/0022-3514.38.2.217.

Canto, J. M., San Martín, J., Perles, F., \& Vallejo, M. (2020). Persons who fear freedom and equality are the ones who most blame women who are victims of acquaintance rape. Violence Against Women, 117. https://doi.org/10.7780/1220909896.

Chapleau, K., Oswald, D., \& Russel, B. (2007). How ambivalent sexism towards women and men support rape myth acceptance. Sex Roles, 57, 131-136. https://doi.org/10.1007/s11199-007-9196-2.
Chapleau, K. M., \& Oswald, D. L. (2013). Status, threat, and stereotypes: Understanding the function of rape myth acceptance. Social Justice Research, 26, 18-41. https://doi.org/10.1007/s11211-013-0177-z.

Chen, F. F. (2007). Sensitivity of goodness of fit indexes to lack of measurement invariance structural equation modeling. Journal of Structural Equation Modeling, 14, 464-504. https://doi.org/10. 1080/10705510701301834.

Dalbert, C. (1999). The world is more just for me than generally: About the personal belief in a just world scale's validity. Social Justice Research, 12, 79-98. https://doi.org/10.1023/A:1022091609047.

Dawes, J. (2008). Do data characteristics change according to the number of scale points used? An experiment using 5-point, 7-point and 10point scales. International Journal of Market Research, 50(1), 61104. https://doi.org/10.1177/147078530805000106.

Debowska, A., Boduszek, D., Dhingra, K., Kola, S., \& Meller-Prunska, A. (2015). The role of psychopathy and exposure to violence in rape myth acceptance. Journal of Interpersonal Violence, 30, 27512770. https://doi.org/10.1177/0886260514553635.

Dénes, V. (2000). A bírósági eljárás sajátosságai a családon belül elkövetett szexuális büncselekmények tárgyalása során. Belügyi Szemle, 127-146 http://konyvtar.bpugyvedikamara.hu/category/ tartalomjegyzekek/folyoiratok/belugyi-szemle/.

European Union Agency for Fundamental Rights (2014): Violence against women: An EU-wide survey. Retrieved from: https:// www.google.hu/url? sa $=\mathrm{t} \& \mathrm{rct}=\mathrm{j} \& \mathrm{q}=\& \mathrm{esrc}=\mathrm{s} \&$ source $=\mathrm{web} \& \mathrm{~cd}=$ $2 \& v e d=0$ ahUKEwih $5 \mathrm{Kr} 6 \mathrm{ujVAhU1MJoKHWKTB}$ 8QFgguMAE\&url=http $\% 3 \mathrm{~A} \% 2 \mathrm{~F} \% 2 \mathrm{~F}$ fra.europa.eu $\% 2 \mathrm{Fsites} \%$ 2Fdefault $\% 2 \mathrm{Ffiles} \% 2 \mathrm{Ffra}-2014$-vaw-survey-main-results-apr 14 en.pdf\&usg=AFQjCNGcAvCEvNEm0iLnwdov4mTbeHPj7A

European Commission. (2016). Special Eurobarometer 449 [Internet]. European Commission. Available from: http://data.europa.eu/.

Faragó, L., \& Kende, A. (2017). Az elnyomás támogatása vagy az egyenlőség ellenzése? Az új Szociális Dominancia Orientáció Skála (SDO7) vizsgálata. Alkalmazott pszichológia, 17, 115-135. https://doi.org/10.17627/ALKPSZICH.2017.1.115.

Foster, C., \& Kidd, G. (2014). Acquaintance rape: Associations between rape myths, blame, and attitudes towards women. Asian Journal of Humanities and Social Studies, 2, 447-457 Retreived from: https:// ajouronline.com/index.php/AJHSS/article/view/1356.

Forbes, G. B., Adams-Curtis, L. E., \& White, K. B. (2004). First-and second-generation measures of sexism, rape myths and related beliefs, and hostility toward women: Their interrelationships and association with college students' experiences with dating aggression and sexual coercion. Violence Against Women, 10, 236-261. https://doi.org/10.1177/1077801203256002.

Frese, B., Moya, M., \& Megías, J. L. (2016). Social perception of rape: How rape myth acceptance modulates the influence of situational factors. Journal of Interpersonal Violence, 19, 143-161. https://doi. org/10.1177/0886260503260245.

Gerger, H., Kley, H., Bohner, G., \& Siebler, F. (2007). The acceptance of modern myths about sexual aggression scale: Development and validation in German and English. Aggressive Behavior: Official Journal of the International Society for Research on Aggression, 33, 422-440. https://doi.org/10.1002/ab.20195.

Gilmartin-Zena, P. (1988). Gender differences in students' attitudes toward rape. Sociological Focus, 21, 279-292.

Glick, P., \& Fiske, S. (1996). The ambivalent sexism inventory: Differentiating hostile and benevolent sexism. Journal of Personality and Social Psychology, 70, 491-512. https://doi.org/ 10.1037/0022-3514.70.3.491.

Glick, P., Fiske, S. T., Mladinic, A., Saiz, J. L., Abrams, D., Masser, B., Adetoun, B., Osagie, J. E., Akande, A., Alao, A., Annetje, B., Willemsen, T. M., Chipeta, K., Dardenne, B., Dijksterhuis, A., Wigboldus, D., Eckes, T., Six-Materna, I., Expósito, F., Moya, M., Foddy, M., Kim, H. J., Lameiras, M., Sotelo, M. J., MucchiFaina, A., Romani, M., Sakalli, N., Udegbe, B., Yamamoto, M., Ui, 
M., Ferreira, M. C., \& López, W. L. (2000). Beyond prejudice as simple antipathy: Hostile and benevolent sexism across cultures. Journal of Personality and Social Psychology, 79, 763-775. https://doi.org/10.1037/0022-3514.79.5.763.

Hafer, C. L. (2000). Do innocent victims threaten the belief in a just world? Evidence from a modified Stroop task. Journal of Personality and Social Psychology, 79, 165-173. https://doi.org/ 10.1037/0022-3514.79.2.165.

Hantzi, A., Efthymios, L., Katerina, T., \& Bohner, G. (2015). Validation of the greek Acceptance of Modern Myths about Sexual Aggression (AMMSA) scale: Examining its relationships with sexist and conservative political beliefs. International Journal of Conflict and Violence, 9, 121-133. https://doi.org/10.4119/ijcv-3072.

Hantzi, A., Efthymios, L., Katerina, T., \& Bohner, G. (2016). Validation of the Greek acceptance of modern myths about sexual aggression (AMMSA) scale: Examining its relationships with sexist and conservative political beliefs. International Journal of Conflict and Violence, 9, 121-133. https://doi.org/10.4119/UNIBI/ijcv.498.

Hayes, R. M., Lorenz, K., \& Bell, K. A. (2013). Victim blaming others: Rape myth acceptance and just world belief. Feminist Criminology, 8, 202-220. https://doi.org/10.1177/1557085113484788.

Ho, A. K., Sidanius, J., Kteily, N., Sheehy-Skeffington, J., Pratto, F., Henkel, K. E., Foels, R., \& Stewart, A. L. (2015). The nature of social dominance orientation: Theorizing and measuring preferences for intergroup inequality using the new SDO7 scale. Journal of Personality and Social Psychology, 109, 1003-1028. https://doi. org/10.1037/pspi0000033.

Kovács, B., \& Szémann, T. (2018) Mégiscsak megváltozott valami a szexuális zaklatások miatt [something has changed as a result of sexual harassment] index.Hu. Retrieved from: https://index.hu/ kultur/2018/10/14/metoo mozgalom szexualis zaklatas felmeres kozvelemeny-kutatas_marton_laszlo_kerenyi_miklos_gabor_ harvey_weinstein/

Kühn, S., Kugler, D. T., Schmalen, K., Weichenberger, M., Witt, C., \& Gallinat, J. (2019). Does playing violent video games cause aggression? A longitudinal intervention study. Molecular Psychiatry, 24, 1220-1234. https://doi.org/10.1038/s41380-018-0031-7.

Lambert, A., \& Raichle, K. (2000). The role of political ideology in mediating judgments of blame in rape victims and their assailants: A test of the just world, personal responsibility, and legitimization hypotheses. Personality and Social Psychology Bulletin, 26, 853863. https://doi.org/10.1177/0146167200269010.

Lenhard, W. \& Lenhard, A. (2016). Calculation of effect sizes. Retrieved from: https://www.psychometrica.de/effect size.html. Dettelbach (Germany): Psychometrica. https://doi.org/10.13140/RG.2.2. 17823.92329

Lerner, M. J. (1980). The belief in a just world: A fundamental delusion. Plenum Press.

Lonsway, K. A., \& Fitzgerald, L. F. (1994). Rape myths. In review. Psychology of Women Quarterly, 18, 133-164. https://doi.org/10. 1111/j.1471-6402.1994.tb00448.x.

Manoussaki, K., \& Hayne, A. (2019). Authoritarianism, social dominance, religiosity and ambivalent sexism as predictors of rape myth acceptance. International journal of gender and women's studies, 7 , 79-84. https://doi.org/10.15640/ijgws.v7n1p10.

McMahon, S. (2010). Rape myth beliefs and bystander attitudes among incoming college students. Journal of American College Health, 59, 3-11. https://doi.org/10.1080/07448481.2010.483715.

McMahon, S., \& Farmer, G. L. (2011). An updated measure for assessing subtle rape myths. Social Work Research, 35, 71-81. https://doi.org/ 10.1093/swr/35.2.71

Ministry of Justice, Home Office, \& Office for National Statistics (2013). An overview of sexual offending in England and Wales. Ministry of Justice, Home Office and Office for National Statistics-Statistics Bulletin. Retreived from: https://www.gov.uk/government/ statistics/an-overview-of-sexual-offending-in-england-and-wales
Montada, L., \& Lerner, M. J. (Eds.). (1998). Responses to victimizations and belief in a just world. Plenum Press. https://doi.org/10.1007/ 978-1-4757-6418-5.

Murphy, A., \& Hine, B. (2019). Investigating the demographic and attitudinal predictors of rape myth acceptance in UK police officers: Developing an evidence-base for training and professional development. Psychology, Crime \& Law, 25, 69-89. https://doi.org/10. 1080/1068316X.2018.1503663.

Muthén, L. K., \& Muthén, B. O. (2009). Mplus. Statistical analysis with latent variables. User's guide, 7.

Muthén, L. K., \& Muthén, B. O. (2015). MPLUS (Version 7.2). [Computer Software]. Los Angeles, CA.

Muthén, L, K. \& Muthén, B, O. (2017). Mplus statistical analysis with latent variables. Users's Guide. Retreived from: https://www. statmodel.com/download/usersguide/MplusUserGuideVer_8.pdf

Nyúl, B., Kende, A., Engyel, M., \& Szabó, M. (2018). Perception of a perpetrator as a successful person predicts decreased moral judgment of a rape case and labeling it as rape. Frontiers in Psychology, 9, 2555. https://doi.org/10.3389/fpsyg.2018.02555.

Papp, L. J., \& Erchull, M. J. (2017). Objectification and system justification impact rape avoidance behaviors. Sex Roles, 76, 110-120. https://doi.org/10.1007/s11199-016-0660-8.

Parti, K. (2002). A letter from Hungary: Raising awareness of domestic violence. Crime Prevention and Community Safety, 4, 65-70. https://doi.org/10.1057/palgrave.cpes.8140132.

Payne, D. L., Lonsway, K. A., \& Fitzgerald, L. F. (1999). Rape myth acceptance: Exploration of its structure and its measurement using the Illinois rape myth acceptance scale. Journal of Research in Personality, 33, 27-68. https://doi.org/10.1006/jrpe.1998.2238.

Peterson, K., Sharps, P., Banyard, V., Powers, R. A., Kaukinen, C., Gross, D., Decker, M. R., Baatz, C., \& Campbell, J. (2018). An evaluation of two dating violence prevention programs on a college campus. Journal of Interpersonal Violence, 33, 3630-3655. https:// doi.org/10.1177/0886260516636069.

Poll of Polls (2018). Hungary. Available at: https://pollofpolls.eu/HU

Pratto, F., Sidanius, J., Stallworth, L. M., \& Malle, B. F. (1994). Social dominance orientation: A personality variable predicting social and political attitudes. Journal of Personality and Social Psychology, 67(4), 741-763. https://doi.org/10.1037/0022-3514.67.4.741.

Reling, T. T., Barton, M. S., Becker, S., \& Valasik, M. A. (2018). Rape myths and hookup culture: An exploratory study of US College Students' perceptions. Sex Roles, 78, 501-514. https://doi.org/10. 1007/s11199-017-0813-4.

Sable, M. R., Danis, F., Mauzy, D. L., \& Gallagher, S. K. (2006). Barriers to reporting sexual assault for women and men: Perspectives of college students. Journal of American College Health, 55, 157162. https://doi.org/10.3200/JACH.55.3.157-162.

Sinclair, H. C., \& Bourne Jr., L. E. (1998). Cycle of blame or just world: Effects of legal verdicts on gender patterns in rape-myth acceptance and victim empathy. Psychology of Women Quarterly, 22, 575-588. https://doi.org/10.1111/j.1471-6402.1998.tb00178.x.

Strömwall, L. A., Alfredsson, H., \& Landström, S. (2013). Blame attributions and rape: Effects of belief in a just world and relationship level. Legal and Criminological Psychology, 18, 254-261. https:// doi.org/10.1080/13552600.2012.683455.

Suarez, E., \& Gadalla, T. M. (2010). Stop blaming the victim: A metaanalysis on rape myths. Journal of Interpersonal Violence, 25, 2010-2035. https://doi.org/10.1177/0886260509354503.

Süssenbach, P., \& Bohner, G. (2011). Acceptance of sexual aggression myths in a representative sample of German residents. Aggressive Behavior, 37, 374-385. https://doi.org/10.1002/ab.20390.

Swim, J., Aikin, K., Hall, W., \& Hunter, B. (1995). Sexism and racism: Old-fashioned and modern prejudices. Journal of Personality and Social Psychology, 68, 199-214. https://doi.org/10.1037/00223514.68.2.199. 
Szabó, M. (2008). A társadalmi nemekkel kapcsolatos dinamikus nézetrendszerek szociálpszichológiai vizsgálata: Ideológiák és sztereotípiák, nemi tipizáltság és társas identitás. $\mathrm{PhD}$ Dissertation, ELTE.

Székely L., Szalayné S, E., Szabó M (2015) „Tehetsz róla tehetsz ellene!” Az alapvető jogok biztosa és helyettesei a rendőrség videoklipjéröl. Retreived from: https://www.ajbh.hu/-/-tehetsz-rola-tehetsz-elleneaz-alapveto-jogok-biztosa-es-helyettesei-a-rendorseg-videoklipjerol

The Global Gender Gap Report (2020) URL: https://www.weforum.org/ reports/gender-gap-2020-report-100-years-pay-equality

Trottier, D., Benbouriche, M., LeBlanc, C., \& Bonneville, V. (2020). Validation française de l'Échelle révisée d'adhésion aux mythes du viol (FR-IRMA) [French validation of the revised Illinois Rape Myth Acceptance Scale]. Canadian Journal of Behavioural Science / Revue canadienne des sciences du comportement, 52(2), 171-176. https://doi.org/10.1037/cbs0000176.

United Nations Development Programme (2019) Human Development Reports. Gender Inequality Index. Retreived from: http:/hdr.undp. org/en/content/gender-inequality-index-gii
Viki, G. T., \& Abrams, D. (2002). But she was unfaithful: Benevolent sexism and reactions to rape victims who violate traditional gender role expectations. Sex Roles, 47, 289-293. https://doi.org/10.1023/ A: 1021342912248 .

Viki, G., Abrams, D., \& Masser, B. (2004). Evaluating stranger and acquaintance rape: The role of benevolent sexism in perpetrator blame and recommended sentence length. Law and Human Behavior, 28, 295-303. https://doi.org/10.1023/B:LAHU. 0000029140.72880 .69 .

Vonderhaar, R. L., \& Carmody, D. C. (2015). There are no "innocent victims" the influence of just world beliefs and prior victimization on rape myth acceptance. Journal of Interpersonal Violence, 30, 1615-1632. https://doi.org/10.1177/0886260514549196.

Publisher's Note Springer Nature remains neutral with regard to jurisdictional claims in published maps and institutional affiliations. 